\title{
THE FLOOD OF OCTOBER 9, 2018 IN THE CITY CENTRE OF SANT LLORENÇ DES CARDASSAR (MALLORCA)
}

\author{
MIQUEL GRIMALT- GELABERT*, JOAN BAUZÀ-LLINÁS, \\ MARÍA C. GENOVART-RAPADO
}

Departament de Geografia, Grup de Recerca CLIMARISC, Universitat de les Illes Balears, Campus Universitari. Edifici Guillem Colom, 07122 Palma, Spain.

\begin{abstract}
Since the 1940s, the city centre of Sant Llorenç des Cardassar has suffered from several flooding episodes from the several tributaries of ca n'Amer creek. Five lives lost and a significant impact on the population were the result of the most relevant flood in the series that occurred in 2018. In this paper, an analysis of the historical relationship of the village with floods, the answer provided by the administration to those floods, and the geographic setting and the anthropic actions on the land are considered. Using the data collected by direct observation, witnesses, and graphs and fieldwork, a thorough investigation of the volume, flow, direction and levels of water has been developed. This translates into an exhaustive mapping of the event, discriminating the hydraulic behaviour in each of the affected roads and showing the sequential development of the flood. Flooding is a combination of severe stream flows, avulsion processes and angular sections that combine with infraestructures that interfere with the flow direction and prevent its reintegration into the main channel and where the streets become active channels.
\end{abstract}

\section{La inundación del 9 de octubre del 2018 en el centro de la ciudad de Sant Llorenç des Cardassar (Mallorca)}

RESUMEN. El núcleo urbano de Sant Llorenç des Cardassar ha sufrido desde la década de 1940 repetidos episodios de inundación por parte de diferentes afluentes del torrent de ca n’Amer. En 2018 se produjo la riada más importante de la serie que provocó un significativo impacto en la población, con 5 víctimas mortales en la misma. En este artículo se analiza la relación histórica de la localidad con los procesos de inundación, la respuesta a los mismos por parte de la administración y el entorno geográfico natural, y las actuaciones antrópicas sobre el territorio. Se lleva a cabo una investigación detallada de los caudales, flujos, direcciones y niveles, todos ellos basados en la observación directa, los testimonios presenciales y gráficos y el trabajo de campo. Ello se traduce en una cartografia exahustiva del evento discriminando el comportamiento hídrico en cada una de las vías afectadas y mostrando el desarrollo secuencial de la inundación. La inundación es el resultado de la combinación entre caudales incidentes extremadamente importantes, procesos naturales de corte en meandros y tramos angulosos que se combinan con infraestructuras que interfieren el flujo del agua e impiden su reintegración al canal principal. Todo ello en un contexto en dónde las calles actúan como elementos de canalización activos.

Key words: Natural hazards, geography of risk, Mallorca, Sant Llorenç, flash flood, urban floods.

Palabras clave: riesgos naturales, geografía del riesgo, Mallorca, Sant Llorenç, flash flood, inundaciones urbanas. 
*Corresponding author: M. Grimalt- Gelabert, Departament de Geografia, Grup de Recerca CLIMARISC, Universitat de les Illes Balears. Campus Universitari. Edifici Guillem Colom, 07122 Palma, Spain. E-mail address: miquel.grimalt@uib.es

\section{Introduction}

The island of Mallorca shows significantly similar physical and territorial features to the Mediterranean coastline of the Iberian Peninsula. Even considering the limiting factors regarding its insularity and the reduced surface of basins, it is also affected by the same flood pattern described in the flash flood model with equally catastrophic consequences to the nearby continental areas. Those events have been historically recurrent (Grimalt, 1992) although in the first years of the 21st century they were less devastating than in other geographical regions nearby such as Murcia (Romero and Castejón, 2014) or the surrounding European Mediterranean territories (Llasat et al., 2013). Floods in island areas with significant tourist development have also been studied in the Canary Islands (López et al., 2019), with evident parallels with the case of the Balearic Islands. In the absence of gauge data, the post-event study of floods using alternative methods offers good results (Bačová et al., 2018; Macchione et al., 2019).

On October 9th 2018, there was a flood in the oriental coastline of Mallorca which affected the municipalities of Sant Llorenç des Cardassar and Artà, as well as Capdepera, and Manacor, to a lesser extent. The event was severe regarding the volume of flow and the associated destruction caused, in particular to the locality of Sant Llorenç des Cardassar and Son Carrió. There were 13 lives lost, which represents an extraordinary death rate considering that in the period between 1960 and the present time (2020) counts with 25 lives lost in Mallorca as a consequence of floods (Grimalt-Gelabert et al., 2020). Out of the 13 deaths registered in October 2018, five were in the city centre of Sant Llorenç, two of them in their place of residence, and three were dragged in vehicles.

This paper characterises the dynamics and analyses the circumstances of the flood in the city centre of Sant Llorenç.

\section{Area of study}

\subsection{Superficial hydrography of Mallorca}

The hydrographic network of Mallorca (Fig. 1) consists of a group of sporadic water flows (referred to as torrent and xaragall). There are no permanent rivers, except for reduced sections that are permanently fed by agrarian drainage systems.

The network is organised in 4 main watersheds, determined by the orography of the land, with two parallel mountain ranges: Serra de Tramuntana and Serres de Llevant, both close to the occidental and oriental coastline, respectively. The central part of the island is located between them, and it is relatively plain. It shows some minor reliefs which subdivide it into two watersheds that lead into the bays in the south occidental and north oriental limits of the island (Palma and Alcúdia). 


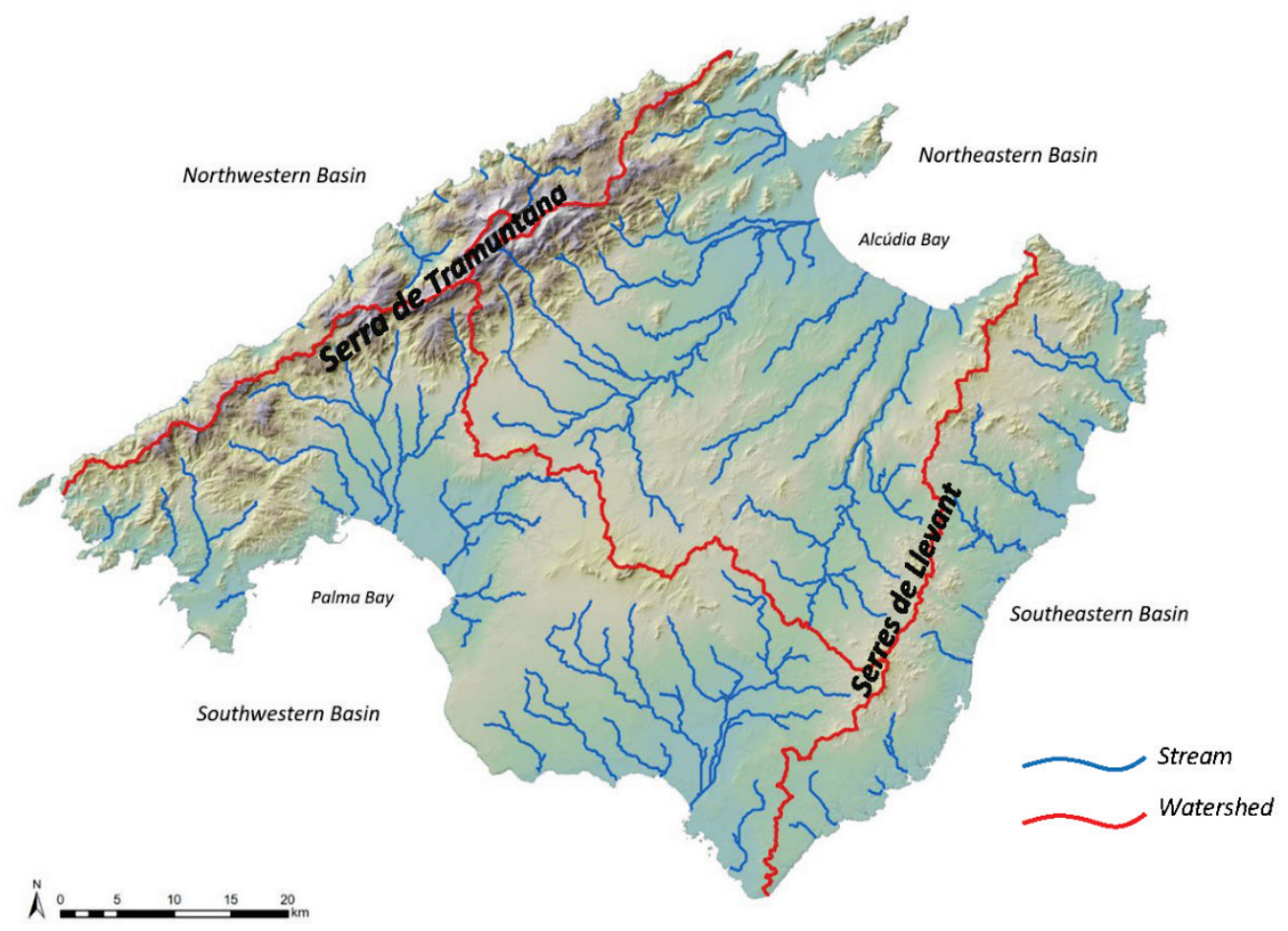

Figure 1. Distribution of the superficial hydrography of Mallorca.

\subsection{Torrent de ca n'Amer watershed features}

The present paper refers to the water flow of ca n'Amer, which is located in the south oriental watershed, formed by a gathering of relatively short tributaries that flow from Serres de Llevant towards the coast. The summits of the mountain range barely reach $500 \mathrm{~m}$ above sea level, but given their proximity to the coast, they register a relatively significant slope (approx $12 \%$ average in the watershed).

These tributary streams follow a NW-SE layout, being the main ones located in the northern side of the basin. A morphometric analysis of the layouts (Grimalt et al., 1990) makes a difference from the creeks in the northern area (torrent de Canyamel, torrent de ca n'Amer, and torrent de ses Taioles) from the other ones.

From a geomorphological point of view, there are several coastal lagoons in the mouth of the main water flows. The high dynamic activity of these lagoons shows the recurrence of flood episodes of high erosive power (Estrany and Grimalt, 2014; Grimalt et al., 1992).

Torrent de ca n'Amer has a basin of an area of $78.07 \mathrm{~km}^{2}$, and a perimeter of $53.6 \mathrm{~km}$ (Fig. 2). It is formed by the gathering of three main tributaries. Several watershed parameters are the elongation ratio (0.65) and Gravelius index (1.7).

Torrent de ses Planes is the main tributary of the course and originates in Puig d'Alpara, with an altitude of 487 metres above sea level. It drains sa Begura/Infern basin, a valley constituted by marlaceous terrains of low porosity in which erosion has caused a notably dense fluvial layout in a land with hills and thalwegs which favour flow gathering. The valley exits through a canyon (Es Gorg) and then receives the tributary torrent de s'Arboçar with very similar density and impermeability features at its headwaters.

The second tributary is torrent de sa Blanquera, rising at Puig de Calicant (473 m above sea level), which flows above marl calcareous soils and lays over a silt clayey plain layout with artificial drainage modifications. Both tributaries join in the immediate city centre of Sant Llorenç des Cardassar. 
The third tributary, xaragall den Fava, rising at Serra de Pocafarina (349 m above sea level), joins the main course in the surroundings of the city centre of Son Carrió.

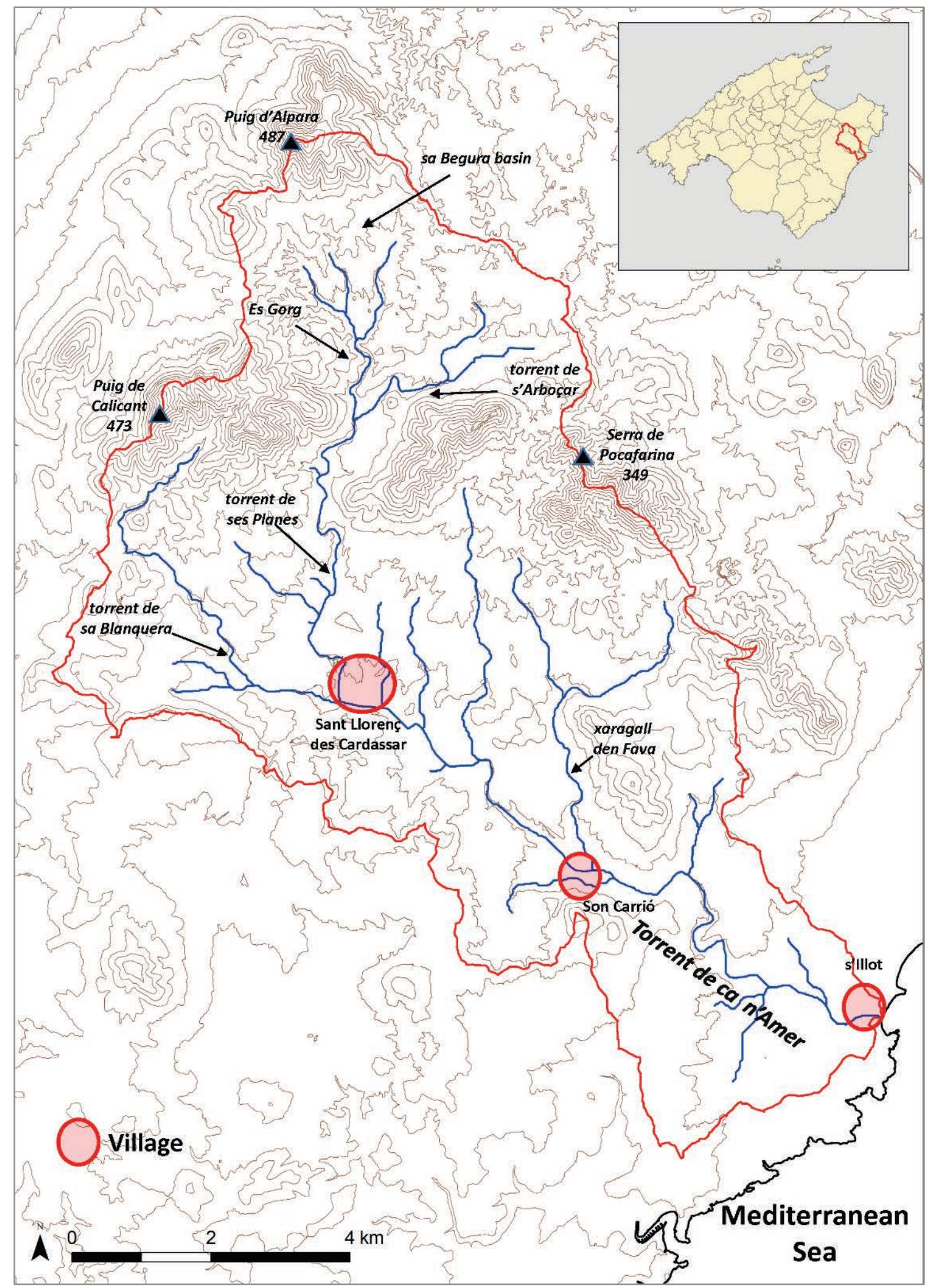

Figure 2. Torrent de ca n'Amer basin. 
From a geomorphological perspective, the rising of all three water flows happens at the axial side of Serres de Llevant, where calcareous and marlaceous materials alternate. They then flow at the foothills, an area of hills and open valleys, which presents a range of land permeability. Their course ends crossing the Miocene platform of Sa Marina, which is extremely karsted and permeable and that digs a meandering canyon.

The mouth features a longitudinal coastal lagoon (Riuet de s'Illot), which has undergone several relevant modifications: it was drained out in 1973, and the 1989 flood subsequently reformed it. After the flood, the administration restored the wetland with a partially coinciding layout with the original one.

\subsection{Torrential rain in the eastern quarter of Mallorca}

The east of Mallorca shows the ideal conditions for episodes of heavy rain, in particular in situations of eastern cyclonic advection or Mediterranean depressions, as in the oriental coastline of the Iberian Peninsula.

There were 68 episodes between 1930 and 2010 which exceeded $100 \mathrm{~mm}$ in 24 hours (Grimalt and Genovart, 2014). The storms on 4th October 1957 (400 mm registered in Santanyí) and the one on the 6th of September 1989 (over 250mm in es Picot, Manacor) are remarkable regarding the amount of rainfall.

$51 \%$ of those episodes happened in cyclonic circumstances, with depressions arround the Balearic Islands, and the eastern cyclonic advection were responsible for $22.45 \%$ of them. A lower percentage of heavy rainfall occurred in undefined atmospheric situations. Season-wise, $85.2 \%$ of the more torrential rainfalls are focused in the second half of the year, from August to December.

\subsection{Previous floods in the area of study}

Torrent de ca n'Amer has historically suffered from numerous severe floods and associated destruction (Table 1). Floods have been documented since the first decades in the 20th century since the growth of the city centres of Sant Llorenç, Son Carrió, and s'Illot sprawled over the adjoining areas to the course of water and flooding translated into the damage of civilian architecture. In the same period of time, there were certain constructions linked to communication (bridges and embankments) which modified the watercourse. Previous to the past century there are a few documentary sources which detail the problems of surface waters in Sant Llorenç related to the insalubrity of dam waters next to the village, but there is no mention to floods. Table 1 summarises the essential information of episodes of flooding in the basin.

Two of the floods mentioned above reached a remarkable volume of water and caused severe destructive effects. On the 30th September 1959, the rainfall focused on the lower basin of the creek, basically on the tributary Xaragall de na Fava. The flood took down the bridge of Pont de ca n'Amer (10 m high) (Rosselló, 1964). One person died, dragged by a minor tributary of Son Moro.

The flood in 1989 affected the oriental and meridional half of the island, with an overflow of all of the tributaries of torrent de ca n'Amer, resulting in the severe destruction in the three inhabited centres of Sant Llorenç. As a result of the draining of the coastal lagoon in the 70 s and the subsequent obstruction of the mouth of the creek, the seaside locality of s'Illot faced the most devastating effects of the flood. Son Carrió, at the downstream of Sant Llorenç also registered disastrous consequences. 
Table 1. Main episodes of flooding in Sant Llorenç 1940-2020. The degree of severeness varies: anecdotic (*), mild $\left({ }^{* *}\right)$, notable $\left({ }^{* * *}\right)$, severe $\left({ }^{* * *}\right)$, and catastrophic $\left({ }^{* * * * *}\right)$. (Grimalt, 1992; Grimalt and Rosselló Geli, 2011; Grimalt et al., 2019).

\begin{tabular}{|c|c|c|c|l|}
\hline Date & Watercourse & Rainfall (mm) & Degree & \multicolumn{1}{|c|}{ Circumstances } \\
\hline 02.11 .1943 & $\begin{array}{c}\text { Torrent de ses } \\
\text { Planes }\end{array}$ & $\begin{array}{c}276 \\
\text { (Son Crespí Vell) }\end{array}$ & $* * *$ & Flood in the city centre of Sant Llorenç. \\
\hline 30.09 .1959 & $\begin{array}{c}\text { Xaragall den } \\
\text { Fava } \\
\text { (Son Servera) }\end{array}$ & $* * * *$ & $\begin{array}{l}\text { It was restricted to the coastline. It floods Son Carrió. } \\
\text { Destroys a bridge (Pont de Ca n'Amer). One life lost, } \\
\text { pedestrian dragged by a minor tributary in a rural area. }\end{array}$ \\
\hline 22.10 .1959 & $\begin{array}{c}\text { Torrent de sa } \\
\text { Blanquera }\end{array}$ & $\begin{array}{c}143.5 \\
\text { (Artà) }\end{array}$ & $*$ & It blocks the road Sant Llorenç-Palma. \\
\hline 12.10 .1973 & $\begin{array}{c}\text { Torrent de ses } \\
\text { Planes }\end{array}$ & $\begin{array}{c}88.5 \\
\text { (Son Crespí Vell) }\end{array}$ & $* * *$ & Flood in the city centre of Sant Llorenç. \\
\hline 29.03 .1974 & $\begin{array}{c}\text { Torrent de ca } \\
\text { n'Amer }\end{array}$ & $\begin{array}{c}143 \\
\text { (es Cabanells) }\end{array}$ & $*$ & Floodings in rural areas. \\
\hline 03.11 .1982 & $\begin{array}{c}\text { Torrent de ses } \\
\text { Planes }\end{array}$ & $\begin{array}{c}103 \text { (es Pou } \\
\text { Colomer Vell) }\end{array}$ & $* *$ & Flood in the city centre of Sant Llorenç. \\
\hline 25.10 .1985 & $\begin{array}{c}\text { Xaragall de sa } \\
\text { Muntanyeta }\end{array}$ & $\begin{array}{c}63.8 \\
\text { (Son Sard) }\end{array}$ & $* *$ & $\begin{array}{l}170 \\
\text { (Can Xesc) } \\
\text { Wlood in the eastern quarter of city centre of Sant } \\
\text { Llorenç. }\end{array}$ \\
\hline 06.09 .1989 & $\begin{array}{c}\text { Whole basin } \\
\text { Severe effects in Sant Llorenç, Son Carrió and s'Illot. } \\
\text { Several bridges and infrastructures collapse. Some } \\
\text { vehicles get dragged. }\end{array}$ \\
\hline 22.11 .2007 & $\begin{array}{c}\text { Torrent de sa } \\
\text { Blanquera }\end{array}$ & $\begin{array}{c}77.2 \\
\text { (Son Carrió) }\end{array}$ & $* *$ & $\begin{array}{l}\text { Flooding in the city centre of Sant Llorenç. It blocks } \\
\text { the road Sant Llorenç-Palma. }\end{array}$ \\
\hline 09.10 .2018 & Whole basin & $\begin{array}{c}257.0 \\
\text { (Sant Llorenç) }\end{array}$ & $* * * * *$ & $\begin{array}{l}\text { Severe effects in Sant Llorenç, Son Carrió y s'Illot. } \\
\text { Several bridges and infrastructures collapse. Numerous } \\
\text { vehicles get dragged. Nine lives lost. }\end{array}$ \\
\hline 20.01 .2020 & Whole basin & $\begin{array}{c}205.6 \\
\text { (Sant Llorenç) }\end{array}$ & $* *$ & $\begin{array}{l}\text { It blocks the road towards Palma. Flooding focused on } \\
\text { Sant Llorenç and Son Carrió. }\end{array}$ \\
\hline
\end{tabular}

\subsection{Downtown Sant Llorenç and hydrographic network}

Sant Llorenç des Cardassar is the main population centre of the homonymous municipality, with 3,545 inhabitants (2018). The historical development of the village initiated in a long hill (76-82 mamsl). In the southwestern edge of the hill there is a church devoted to Saint Lawrence, after whom the village is named. This raised area served as the origin of the first road layout, as well as several constructions that stretched to the north, following the topography of the area and sprawling laterally.

As a consequence, the origins of the locality were a nucleus located over a piece of raised land, limited by the main course of water in the system, torrent de Ses Planes, and with a minor stream of water limiting the north oriental part of the settlement (xaragall de sa Muntanyeta). In the first decades of the 20st century, the building expanded towards the south and the west. It moved towards the foothill next to torrent de ses Planes in a lesser elevated topographic level in relation to the hydric course.

Torrent de ses Planes in the urban surroundings of Sant Llorenç flows relatively fitted into a valley of unsymmetrical topography (Fig. 3). In the first pre-urban section, the northern bank is raised, with a small cliff, where the cemetery is located, and that coincides with the occidental edge of the topographic hill from the original urban layout.

Next, the characteristics of the terrain change. The torrent has the west bank that coincides with an elevation and the east bank -where the lower part of the town is located-is almost at the same level as the channel.

Finally, after receiving the contributions from the tributary of sa Blanquera, the southern bank of the canal is elevated, while the northern bank, which borders the urban nucleus, is not elevated in relation to the channel. 


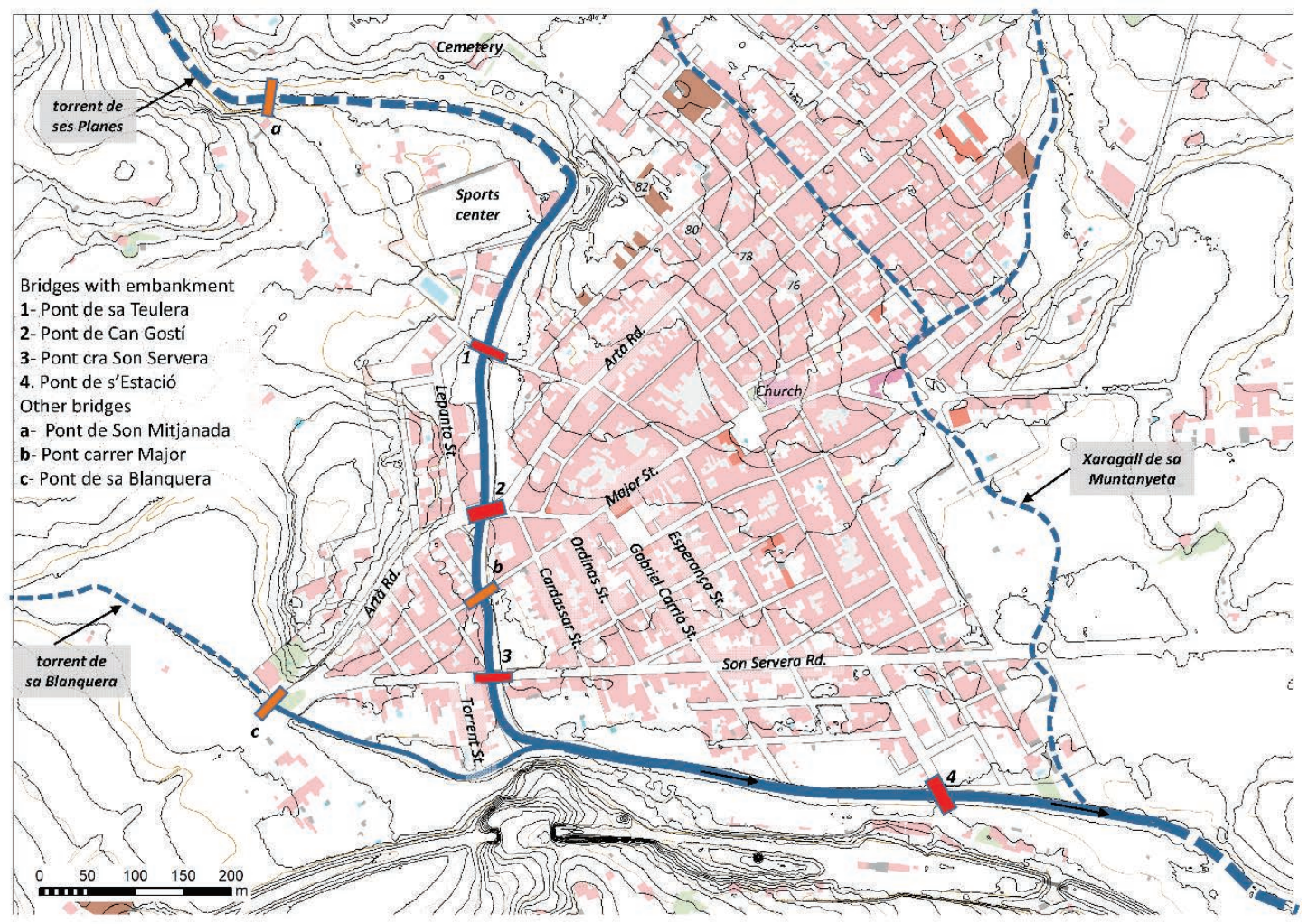

Figure 3. City centre of Sant Llorenç des Cardassar. Topography (contour interval 2 m) and hydrography. Main urban toponyms.

2.6. Alterations of the watercourse of torrent de ses Planes in the city centre of Sant Llorenç des Cardassar

In the second half of the 20th century, the layout of the watercourse through the city centre has undergone several modifications, some of them as a response to floods (Fig. 4).
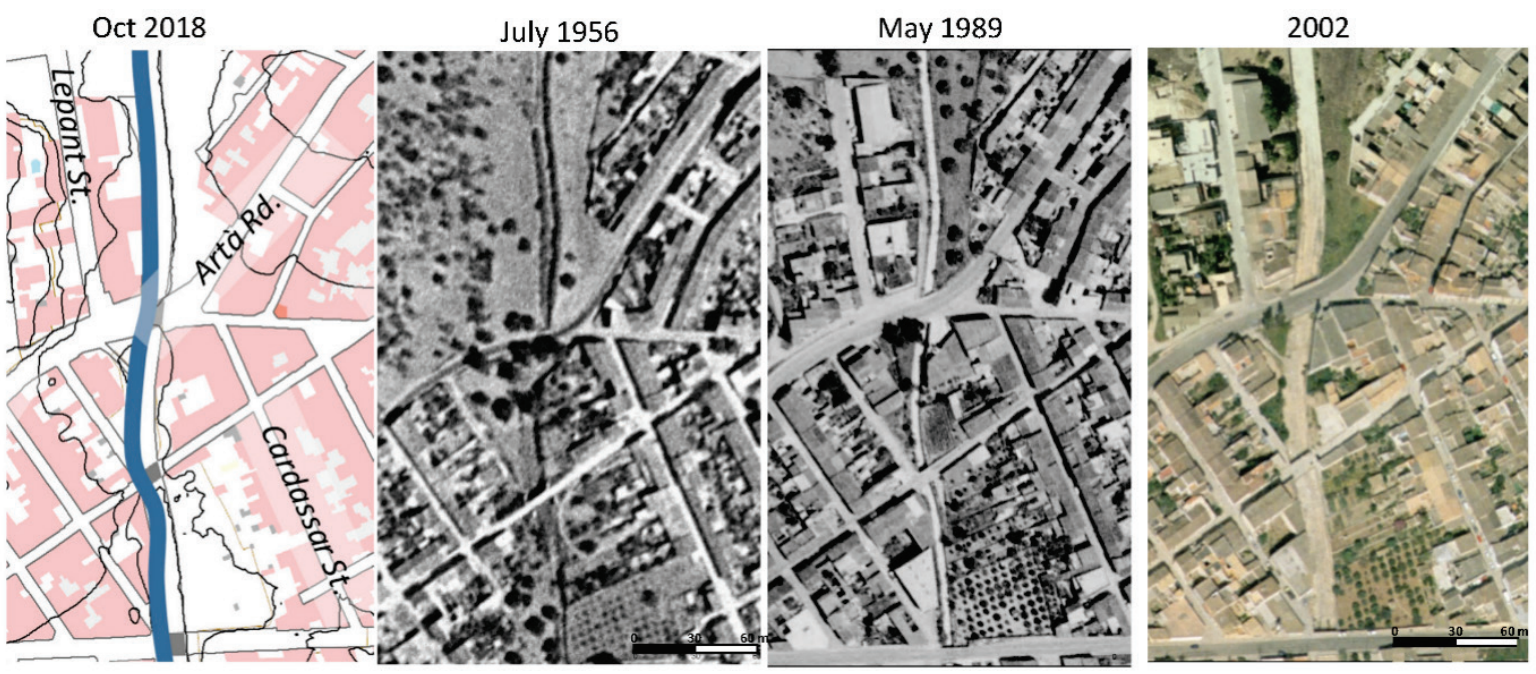

Figure 4. Aerial view of Sant Llorenç, which was already settled in 1956. Between 1970 and 1998, only a few warehouses and buildings were added in the area close to the watercourse, and the streets surrounding Lepant street were built. The watercourse was upgraded from a small canal (1956) to an artificial 4-metreswide cemented canal in the 70s and 90s. In 1990 it was widened to 12 m, after the flash-flood in 1989. 
Until the 70s, the torrent did not have any sort of artificial channeling, being back then a stream with the minimum dimension as to allow the scant usual water flow. In the first years of the decade, it was regularised and transformed into a cemented, walled canal but of reduced capacity (4 m width - 1.2 m depth).

The flash-flood of the 12th of October 1973 proved the construction insufficient since the course overflowed in the same flow direction that it would in later events. As a response, there were several upgrading proposals which involved the building of a dam (Grimalt, 1992), which were never executed.

The flash-flood of 1989 wiped out or compromised the integrity of the majority of the existing bridges over the watercourse. Upstream, the estimated water flow calculated with geomorphological methods is $252 \mathrm{~m} / \mathrm{s}$. The response of the Regional Authorities was to expand the canal to $12 \mathrm{~m}$ wide and $2 \mathrm{~m}$ deep, with an average slope of $0.008 \mathrm{~m} / \mathrm{m}$. The bridges were rebuilt with a rectangular span fitted to the canal measurements.

The remarkable size of the new canal provided the population with a sense of security, even though its capacity (of approximately $140 \mathrm{~m}^{3} / \mathrm{s}$ in ideal conditions in the initial section) was below the water flow registered in the flash-flood that had pushed its building. The satisfaction of the population with the new canal was reinforced after a heavy rainfall in 1990 when it proved capable of containing the presumable overflow that would have been registered in the previous circumstances. However, the new water bank did not encourage more building in the immediate surroundings, since the sporting facilities, buildings or warehouses close to the watercourse which were affected by subsequent floods were previous to the widening of the canal.

\section{Objectives and methodology}

The present paper aims at analysing the flood processes suffered in the city centre of Sant Llorenç des Cardassar during the episode of 9th October 2018. Water levels have been found out and mapped, main stream flow lines are established and natural and anthropogenic factors that have caused the phenomenon are investigated.

In the period between October 2018 and April 2019, there has been a direct information gathering, as well as evidence to achieve the set goal. Since there are no official gauging stations in the basin, the investigation has been developed using geomorphologic evidence, along with alternative information sources (Portugués et al., 2016; Macchione et al., 2019; Segura-Beltran et al., 2016). The marks of high water have allowed the estimation of the height of the flood, water flow and flow direction both in the water bank and in the affected urban areas, registered through a systematic check in the field.

These data have been contrasted with graphic documents, photos, and videos, allowing a better estimation of the flow and its features, in addition to the chronology of the event, flow direction, and the speed of the water flow. Interviews with direct witnesses of the event, as well as a compilation of experiences and interviews by Josep Cortès (Cortès, 2019), have also been used to complete and contrast data. Part of the research group were also witnesses of the event, which supplies live data observation on-site.

\subsection{Peak discharge estimation}

A combination of several methods has been used in order to estimate the peak discharges.

In the urban grid plan, data collected in Grimat et al. (2019b) and the technical report (Grimalt et al., 2019a) have been considered. The calculations derive from the usage of Manning and Riggs formula. 
The peak discharges in non-urban areas has been calculated establishing a channel cross-section departing from the high-water marks left on vegetation and structures. Following similar methodology as Rico and Benito, 2002 or Grimalt and Rodríguez, 1990. The peak discharge is established with additional information about the slope, hydraulic radius, and water depth, along with the diameter of dragged subspherical boulders.

The measurements have been taken in unhindered locations with no change in the direction of the channel. Fieldwork was done in the two following weeks after the episode, counting with pieces of evidence left by wood debris, which accurately show the reached water levels.

In order to quantify the runoff, diverse alternative and complementary methodologies have been used, keeping those used in previous studies (Grimalt and Rodríguez, 1990) in the same area.

The two kinds of empirical formulas are:

- The formulas that determine the peak discharge from the slope of the channel and the crosssection of channel stages: Riggs formula (Riggs, 1976), and Manning (quoted by Dalrymple and Benson, 1989).

- The formula that shows peak flood velocity considering the diameter of water-dragged boulders. With this method, established by Costa (1983), the volume of water is calculated multiplying the speed times the section. To apply the formula, the diameter of the five most voluminous boulders was measured. Only those with a subspherical shape were considered, which is those with a length lower than two-thirds of the biggest longitude.

Riggs formula discharge flow as in:

$$
\mathrm{Q}=3.39 \mathrm{At}^{1.39} \mathrm{~S}^{0.32}
$$

Where $Q$ represents the discharge in $\mathrm{m}^{3} / \mathrm{seg}$, At is the cross-sectional area in $\mathrm{m}^{2}$, and $S$ is the slope in $\mathrm{m}$ per $\mathrm{m}$. For the present study, slope (applied in both Riggs and Manning formulas) was obtained with a digital elevation model with a spatial resolution of $2 \mathrm{~m}$, generated for this study from Lidar files (density of 0,6 points per meter) from a 2014 flight by Instituto Geográfico Nacional.

Manning equation was used in its initial form:

$$
\mathrm{Q}=1 / \mathrm{n} \text { At } \mathrm{R}^{0.66} \mathrm{~S}^{0.5}
$$

Where $Q$ is discharge in $\mathrm{m}^{3} / \mathrm{s}, n$ is the roughness coefficient, At is the section of the channel in $\mathrm{m}^{2}, R$ the hydraulic radius, and $S$ slope channel in $\mathrm{m}$ per $\mathrm{m}$.

In the measuring areas where there were subspherical boulders, Costa equation was applied in order to calculate peak flood velocity:

$$
\mathrm{Vc}=0.18 \mathrm{Dm}^{0.49}
$$

In which $V c$ is peak flood velocity according to Costa in $\mathrm{m} / \mathrm{seg}$, and $D m$ is the average diameter of dragged subspherical boulders.

The final discharge was established as the average of Riggs and Costa formulas. The flow calculated with Manning equation was used as a referencing element and possible measuring error indicator. If Manning value differed significantly from the other formulas, the point would not be considered.

If the discharge calculated with the Costa method showed a lower value as compared to the other formulas, the value would not be considered, since the anomaly is attributed to the lack of boulders. 


\subsection{Analysis of the behavior of overflowing water}

The analysis of the flood in the urban area was determined by the marks left behind by the water in building façades and street furniture. The flow direction has been established from the visualisation of images, witnesses and material evidence. It must be taken into account that the flow in certain areas was in sections of very low/nonexistent slope.

The data available from the state-owned company SITIBSA, which manages the cartography of the Balearic Islands, has been used to extract cartographic information. In addition to that, the group has generated some digital modelling of terrain using the point file as in Lidar from the 2014 flight by Instituto Geográfico Nacional de España. The information from the 1956, 1973, 1989, 2002, 2015, and 2019 flights, also available from the same source, has also been taken into consideration for the interpretation of orthophotos.

\section{Flooding episode on 9th October 2018 in downton Sant Llorenç}

\subsection{Rainfall on 9th October 2018}

The flood on 9th October 2018 was linked to a storming episode of constant regeneration, defined by Doswell et al., (1996) as convective train. The rainfall was particularly heavy upstream of torrent de ca n'Amer, affecting some other watercourses in the same basin (torrent de Canyamel, torrent de ses Talaioles), and Alcudia's basin (torrent de na Borges).

The storm was static, favoured by the relief, and fed by a mild eastern flow. It originated in the south of the basin and it moved extremely slowly towards the north. Rainfall reached $200 \mathrm{~mm}$ in a wide area (Table 2) that covers from the litoral of Alcudia bay to the north up to Sant Llorenç city centre.

Table 2. Rainfall during the episode. Source: AEMET (*), Meteobaleares (**), Particular (***).

\begin{tabular}{|c|c|c|c|}
\hline Observatory & $\begin{array}{c}\text { Rainfall } \\
9 \text { october } 2018 \\
(\mathrm{~mm})\end{array}$ & $\begin{array}{l}\text { Max. rainfall in an } \\
\text { hour }(\mathrm{mm})\end{array}$ & $\begin{array}{l}\text { Max. rainfall in } 10 \\
\text { min. }(\mathrm{mm})\end{array}$ \\
\hline \multicolumn{4}{|c|}{ (Torrent de ca n’Amer basin) } \\
\hline Sant Llorenç (*) & 220.0 & & \\
\hline Sant Llorenç $(* *)$ & 257.0 & 51.6 & 9.4 \\
\hline Son Garriga $(* * *)$ & 217.0 & & \\
\hline Son Carrió $(* *)$ & 184.4 & 76.0 & 17.2 \\
\hline Son Carrió Son Fred $(*)$ & 209.5 & & \\
\hline \multicolumn{4}{|c|}{ (surrounding area) } \\
\hline Manacor Son Crespí (*) & 121.0 & & \\
\hline Artà (*) & 149.8 & 56.8 & 15.4 \\
\hline Son Servera Son Sard & 97.2 & & \\
\hline
\end{tabular}

The time-intensity is more remarkable than the total rainfall, featuring heavy rains that alternated with light drizzling. The chart from Son Carrió observatory (Fig. 5), in lapses of 10 minutes, evidences this alternance.

The flood, as a consequence of prolonged rainfall, rose relatively slowly in level in comparison to the usual timing of flash floods in the oriental watershed of Mallorca. The rising constantly swelled over $15 \mathrm{~min}$ (personal observation), which contrasts with the preceding flood in 1989, where the rising reached the maximum flow almost immediately with no previous flow. 


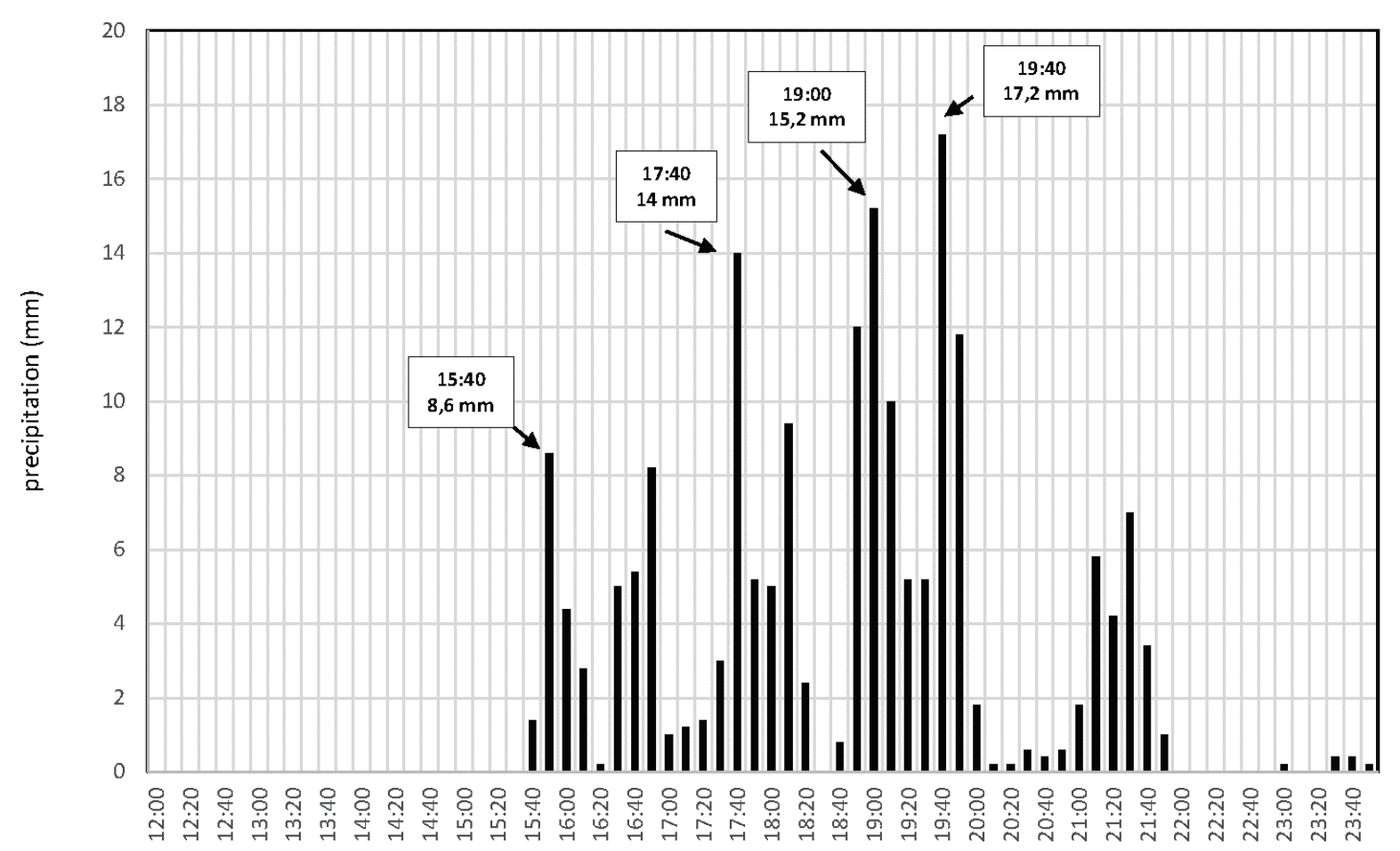

time

Figure 5. Rain distribution from Son Carrió observatory. The episode initiated at 15:30 h and lasted until 22:00 $\mathrm{h}$. There are several peaks of intensity, being the one between 18:50-19:50 h the most remarkable one, with $76 \mathrm{~mm}$ in an hour span. The peak flood happens this same hour.

The relatively slow rising allowed, within minutes, for people to find shelter. Even so, for the same reason, some vehicles kept in motion regardless of the increasing water level. The peak, which extended for half an hour, provoked severe material compromise of urban furniture and both personal belongings and commercial goods.

\subsection{Flows upstream Sant Llorenç in 2018}

An estimation of the peak flow has been made through geomorphologic systems, which allows for an estimated calculation of the magnitude of the event.

In the 1989 flood (Grimalt and Rodríguez, 1990), torrent de ses Planes registered a maximum $113 \mathrm{~m}^{3} / \mathrm{s}$ (within a $41 \mathrm{~m}^{2}$ section), which increased after joining the tributary torrent de s'Arboçar to $245 \mathrm{~m}^{3} / \mathrm{s}\left(80 \mathrm{~m}^{2}\right)$, being the latter the peak that reached the urban area. In the same locations, the peak in 2018 was significantly higher, with an estimated flow of $426.33 \mathrm{~m}^{3} / \mathrm{s}$ and $631.63 \mathrm{~m}^{3} / \mathrm{s}$ in respective sections of $71.44 \mathrm{~m}^{2}$ and $119.54 \mathrm{~m}^{2}$.

Torrent de ses Planes reached the surroundings of Sant Llorenç (Fig. 6) in a straight line, confined in a valley with no flooding plain, with a section of $122.43 \mathrm{~m}^{2}$, which translated into a peak of flow close to $750 \mathrm{~m}^{3} / \mathrm{s}$. When it entered the meander upstream of the village, both the section and flow were reduced, redirecting the flow towards sporting facilities. At the moment of reaching the first urban bridge, the peak had been reduced to a section of $115.7 \mathrm{~m}^{2}$, and flow of $533.6 \mathrm{~m}^{3} / \mathrm{s}$, which represents sensibly lower values. 

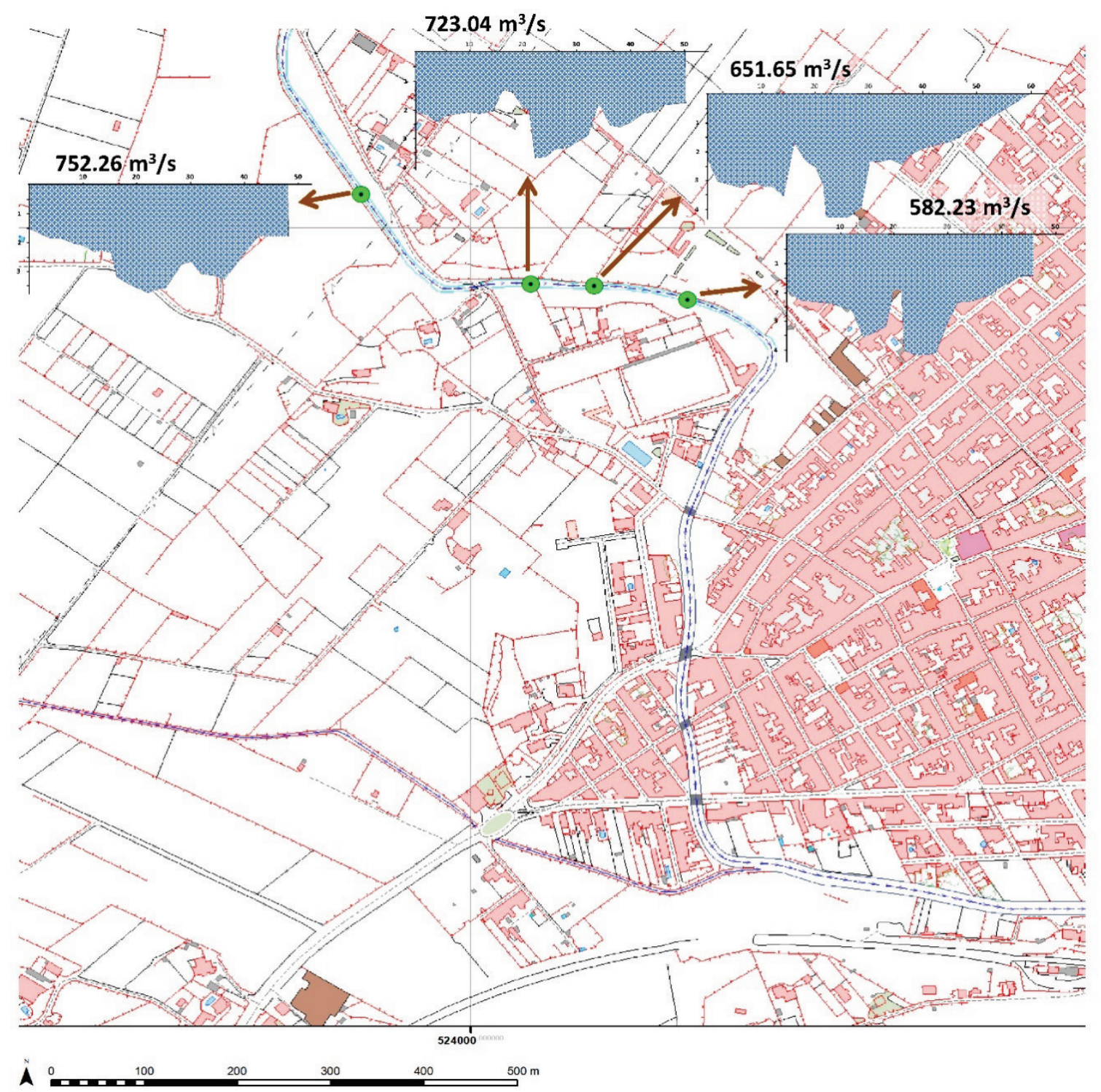

Figure 6. Sections in the area preceding the entrance of torrent de ses Planes to the village.

Regardless of the overflow, the rise exceeded the capacity of the channel built in 1990, as well as the capacity of the first bridge (Pont de Sa Teulera), which decreased as a result of the debris and sediments carried by the water. The loss of capacity of the bridge and the dam effect due to the bridge embankment resulted in an increase of the water level upstream and the diversion of flow into neighbouring streets. It also prevented the flow that had gone through the sporting facilities to reintegrate into the main watercourse.

The resulting flow values could seem extremely high, considering that they are calculated in areas of relatively imprecise lateral limits. However, an unequivocal section of the flood in the road-rail bridge (Fig. 7) downstream from Sant Llorenç, with a span of $100 \mathrm{~m}^{2}$, shows that it operated to maximum capacity, which supports the estimation of $600 \mathrm{~m}^{3} / \mathrm{s}$. 
The flash-flood of October 2018 in torrent de Ses Planes was the most relevant documented flood until the present time. Torrent de sa Blanquera presented an ordinary raise and it did not overflow the existing channelling. Also it was lower than previous episodes such as the ones in 1989, 2007, or even past events (2020). That is why the analysis is focused on the first watercourse.

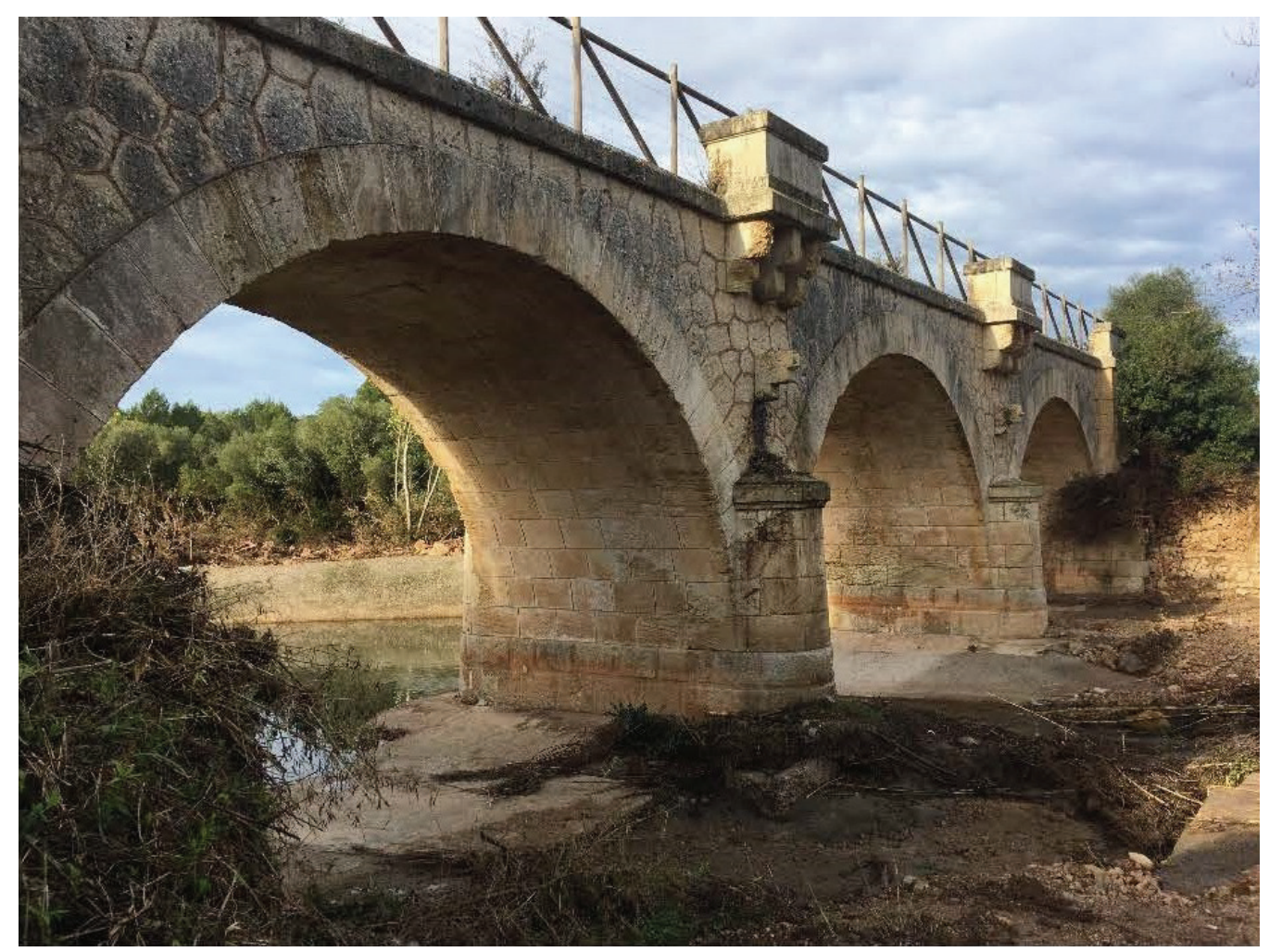

Figure 7. Rail-road bridge over torrent de ca n'Amer, with a total span of $100 \mathrm{~m}^{2}$. During the flood in 2018 it worked to its limit, being used as flow control point.

\subsection{Urban flood}

\subsubsection{Sequential development of flooding in the urban area}

The development of the flood in the urban area is described based on the cartography of the stages of the process. (Fig. 8, 9, and 10).

The bridge Pont de Can Gostí goes across torrent de ses Planes, holding the road to Artà. The span of the bridge was not wide enough to allow the watercourse since the surrounding buildings to both sides prevented the overflowing water from reintegrating to the main watercourse. As a consequence, a remarkable part of the waters flow leaning east towards the city centre. The street that leads towards the east flooded up to $2,85 \mathrm{~m}$ above the pavement. From that point, following the slopes, the overflowing water entered Cardassar, Ordines, Gabriel Carrió, and Esperança streets, at a high speed (3 to $4 \mathrm{~m} / \mathrm{s}$ ). The perpendicular streets to the previous ones flooded slowly. 
Grimalt- Gelabert et al.

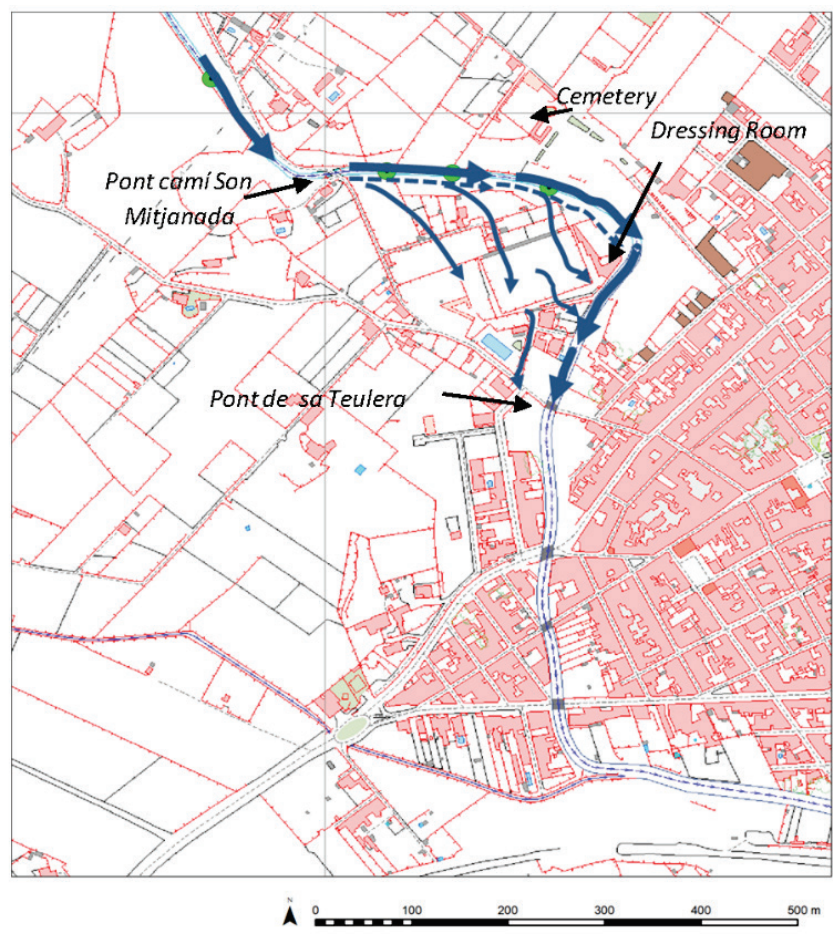

Figure 8: Simplified cartography of the watercourse previous to the urban area. Flood flows in two parallel canals to the changing rooms of the sporting facilities. There are overflowing waters in the whole section leading south, shortcutting the meander. From the northern side, the flood reaches the cliff meeting the cemetery and damaging it partially. Dressing rooms hinder the water flow and provoke an increase in the water level. Downstream towards the football stadium, water is favoured by a small topographic prominence where the pool is and it flows towards the bridge Pont de sa Teulera.

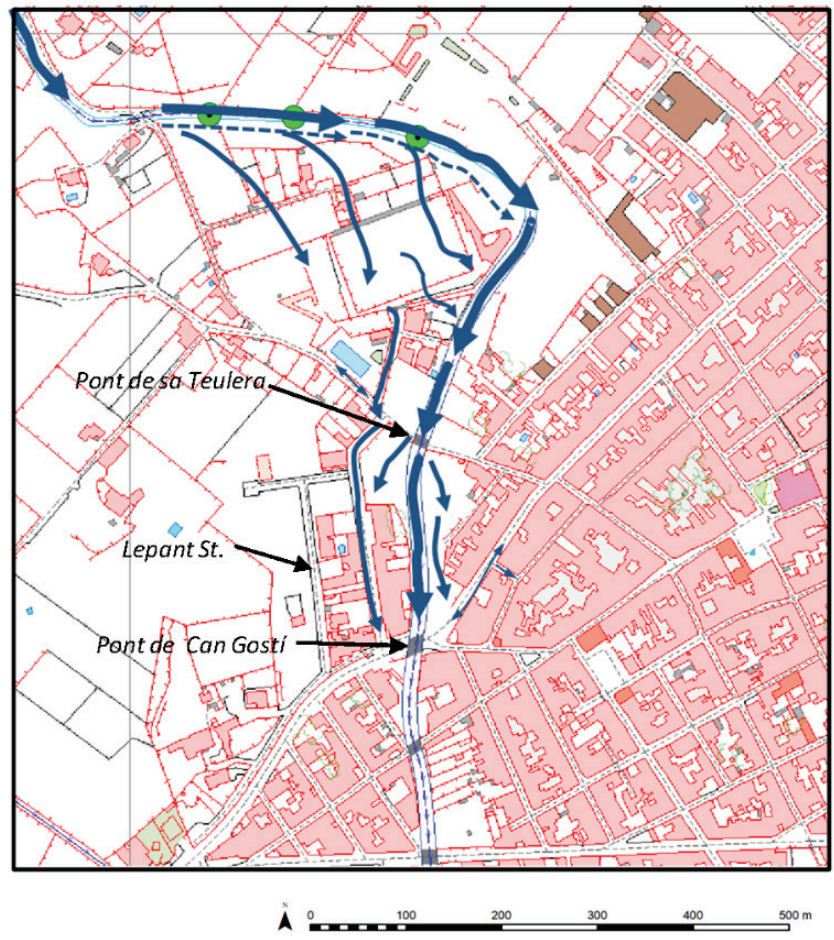

Figure 9. Scheme of overflow from the bridge Pont de Sa Teulera. The flood forks on both banks as a consequence of the dam effect of the bridge and its embankment To the west, it streams down the Lepant st. and reaches levels up to $1.8 \mathrm{~m}$ above the pavement. To the east, it floods some gardens and damages the road. Due to the insufficient bridge capacity, it makes the level of water rise up to $2.85 \mathrm{~m}$ in the surrounding streets. 


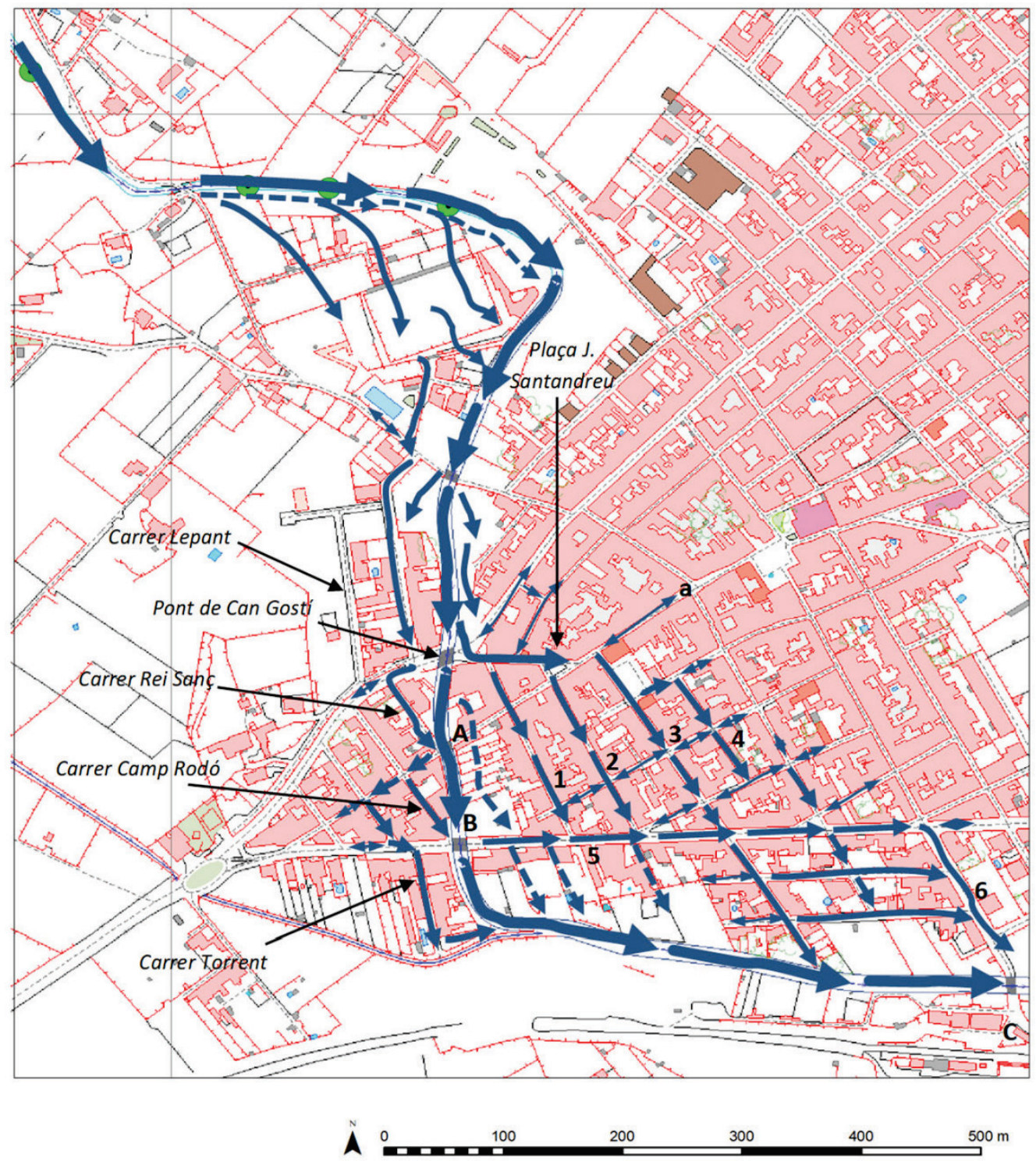

Figure 10. General scheme with flooding lines in the downtown of Sant Llorenç provoked by the dam-effect of the bridge Pont de Can Gostí. The flood to the west went upstream in Major street (a), and flooded Cardassar, Ordines, Gabriel Carrió, and Esperança streets (marked with numbers 1-4). Cardassar and Ordines streets do not lead to the watercourse, but they finish when crossing the road to Son Servera (number

5). The flow of water did not manage to reach the torrent until the end of the streets Gabriel Carrió and Carrer de la Mar (number 6). On the westbound of the torrent, the overflowing waters reached street Lepant and moved on through streets Rei Sanç and Camp Rodó towards the road to Son Servera. Afterwards, they led into torrent de Sa Blanquera. The two bridges of insufficient span in Major street (marked as A), and in the road to Son Servera (marked as B) also hindered the reintegration of overflow water to the main course and contributed to the expansion of the flooded area. Even having an insufficient span, the bridge Pont de s'Estació (marked as C) did not obstruct the watercourse.

\subsubsection{Volume of overflow in the main streets}

Applying the Manning formula, the volume of water flowing through the main streets has been calculated (Table 3 and Table 4), considering a high roughness rate corresponding to the pavement and the debris dragged by the water flow. Observing the videos, the accuracy of the speeds derived from the application of the formula described has been verified. 
Table 3. Water levels, wet section, slope, and volume of water in the west bank of Torrent de ses Planes.

\begin{tabular}{|c|c|c|c|c|c|c|c|}
\hline Street & $\begin{array}{c}\text { Street } \\
\text { width } \\
\text { (m) }\end{array}$ & $\begin{array}{c}\text { Water } \\
\text { level } \\
\text { (m) }\end{array}$ & $\begin{array}{c}\text { Section } \\
\left(\mathbf{m}^{2}\right)\end{array}$ & $\begin{array}{c}\text { Wetted } \\
\text { perimeter }\end{array}$ & $\begin{array}{l}\text { Hydaulic } \\
\text { radius }\end{array}$ & $\begin{array}{l}\text { Slope } \\
(\mathbf{m} / \mathbf{m})\end{array}$ & $\begin{array}{c}\text { discharge } \\
\left(\mathrm{m}^{3} / \mathrm{s}\right)\end{array}$ \\
\hline Lepant & 9.5 & 1.8 & 17.1 & 13.1 & 1.305 & 0.0125 & 75.98 \\
\hline Rei Sanç & 6 & 2.5 & 15 & 11 & 1.364 & 0.013 & 69.96 \\
\hline Torrent & 6.5 & 1.3 & 8.45 & 9.1 & 0.929 & 0.017 & 34.97 \\
\hline Camp Rodó & 6 & 1.5 & 9 & 9 & 1 & 0.035 & 36.74 \\
\hline
\end{tabular}

Table 4. Water levels, wet section, slope, and volume of water in the east bank of Torrent de ses Planes.

\begin{tabular}{|l|c|c|c|c|c|c|c|}
\hline \multicolumn{1}{|c|}{ Street } & $\begin{array}{c}\text { Street } \\
\text { width } \\
(\mathbf{m})\end{array}$ & $\begin{array}{c}\text { Water } \\
\text { level } \\
(\mathbf{m})\end{array}$ & $\begin{array}{c}\text { Section } \\
\mathbf{( m}^{\mathbf{2}} \mathbf{)}\end{array}$ & $\begin{array}{c}\text { Wetted } \\
\text { perimeter }\end{array}$ & $\begin{array}{c}\text { Hydaulic } \\
\text { radius }\end{array}$ & $\begin{array}{c}\text { Slope } \\
\mathbf{( m / \mathbf { m } )}\end{array}$ & $\begin{array}{c}\text { discharge } \\
\left(\mathbf{m}^{\mathbf{3}} / \mathbf{s}\right)\end{array}$ \\
\hline Cardassar & 5.5 & 1.8 & 17.1 & 9.2 & 1.076 & 0.0086 & 32.12 \\
\hline Ordines & 5.5 & 2 & 15 & 9.5 & 1.158 & 0.011 & 42.36 \\
\hline Gabriel Carrió (N) & 7 & 1.4 & 8.45 & 9.8 & 1 & 0.014 & 38.65 \\
\hline Gabriel Carrió (S) & 8.5 & 1.4 & 9 & 11.3 & 1.053 & 0.014 & 48.56 \\
\hline Cardassar & 5.5 & 1.8 & 17.1 & 9.2 & 1.076 & 0.0086 & 32.12 \\
\hline Ordines & 5.5 & 2 & 15 & 9.5 & 1.158 & 0.011 & 42.36 \\
\hline
\end{tabular}

The observed water flows are remarkable, bound to significant speeds, equal or superior to 3 $\mathrm{m} / \mathrm{s}$, which explains the capacity of the water to drag urban furniture or vehicles found in the course. Considering these values (Fig. 11), it can be noticed that, from the bridge Pont de Can Gostí, the runoff in the streets on the western bank was $69.9 \mathrm{~m}^{3} / \mathrm{s}$, corresponding to the street Rei Sanç. The runoff in the streets on the easten bank was $121.3 \mathrm{~m}^{3} / \mathrm{s}$ (corresponding to the sume of flow of several streets).

It is considered that the urban flow of the flood upstream from the mentioned bridge was of 530 $\mathrm{m}^{3} / \mathrm{s}$. A considerable share $\left(191.2 \mathrm{~m}^{3} / \mathrm{s}\right.$, that is $36.08 \%$ of the flood) flowed through the streets and reintegrated to the main channel with a certain difficulty. It redirected in parallel to the road to Son Servera, which is in a higher topographic level than the main watercourse. All the streets parallel to the flow direction became active channels with flows at high velocity since the streets slope was equal to or greater than that of the main channel of the torrent.

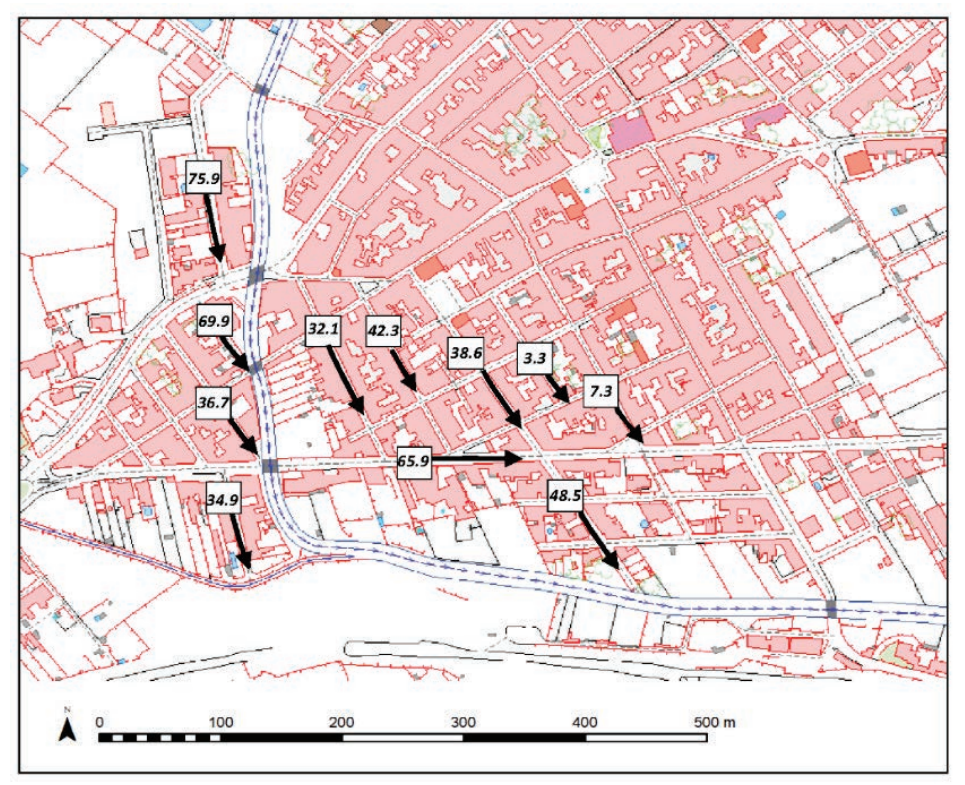

Figure 11. Peak flow in Sant Llorenç des Cardassar (in $\mathrm{m}^{3} / \mathrm{s}$ ) and flow direction in the main affected streets. 


\subsubsection{Levels reached by the flood}

Through fieldwork, 230 water level heights above the pavement have been listed, as well as a precise limitation of the areas affected by the flood. With this information, the maximum levels of the flood in the urban area have been cartographed (Fig. 12).

There were two areas which reached critical levels:

The first one follows the watercourse, with level of up to $5.5 \mathrm{~m}$ upstream the bridge Pont de Can Gostí. Water marks over the channel surpassed $3 \mathrm{~m}$ at all times. There is an increase/decrease path of the watermark related to the interferences provoked by all the bridges.

The second area which reached critical levels starts in the bridge Pont de Can Gostí and it expands to the streets Cardassar, Ordinas, and Gabriel Carrió to join with the road to Son Servera, parallel to the main watercourse.

The hindering provoked by vehicles or debris occasionally rose the levels, but it never determined the direction of the flow, which was governed by more relevant factors such as the slope or water level. That is why it has not been considered in the development of cartography.

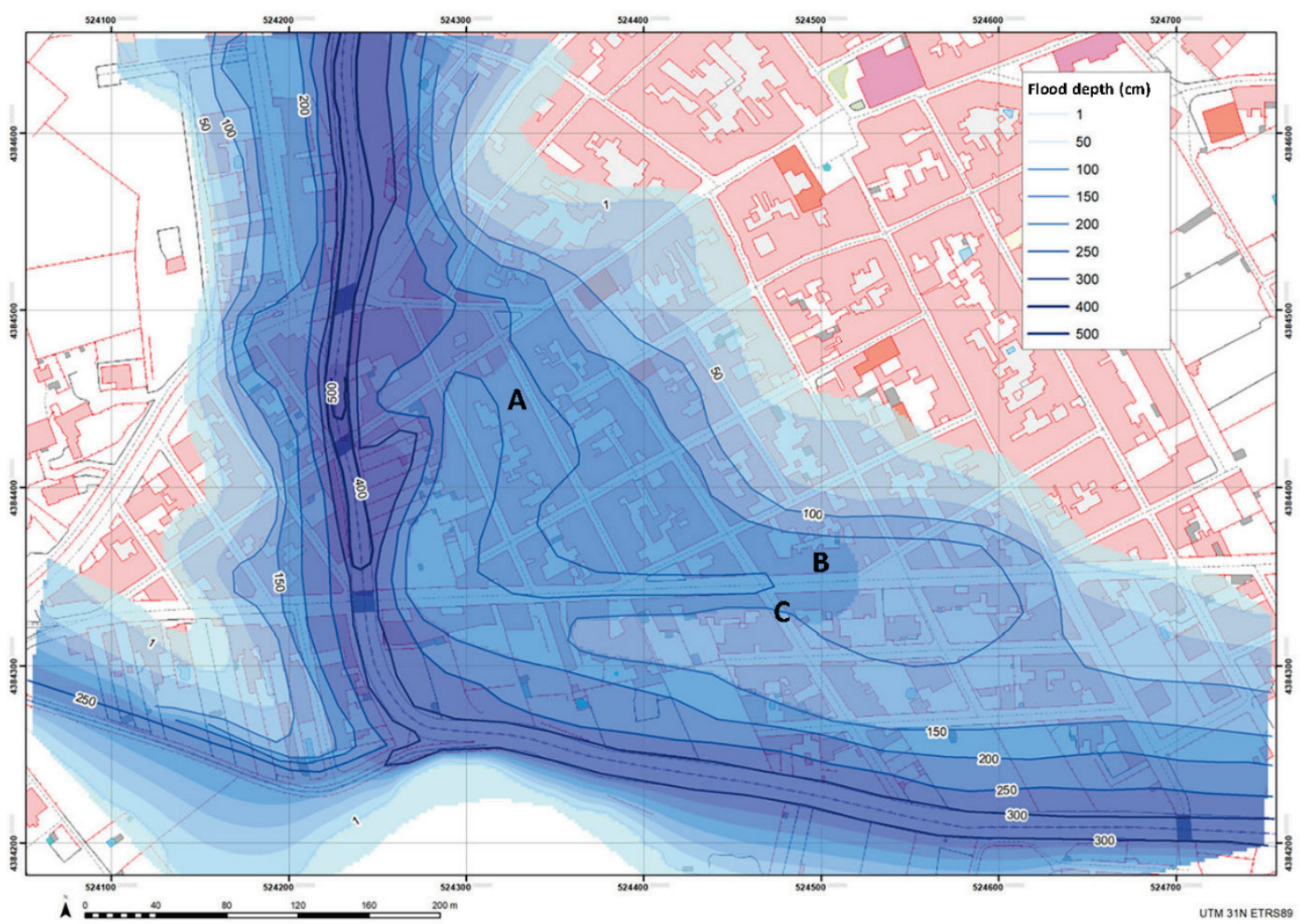

Figure 12. Cartography of the water levels, which were over $1.5 \mathrm{~m}$, mainly in the lower part of the city. This height, together with the remarkable speed of the flow, resulted in the water swiping parked cars, as well as favoured water to smash doors and windows, flooding the interior of dwellings. The urban flooding also killed two people in buildings located in Ordinas street (A) and on the road to Son Servera (B). Three more people were killed in their vehicles, the first one in the bridge Pont de Son Mitjanada, and the second one in the road to Son Servera $(C)$. 


\subsubsection{Obstructions of the water course and their effects}

The behaviour of the flood in the urban area is related to several circumstances that combine the natural features of the terrain with the urban layout and some other isolated factors which hindered the watercourse (Fig. 13).

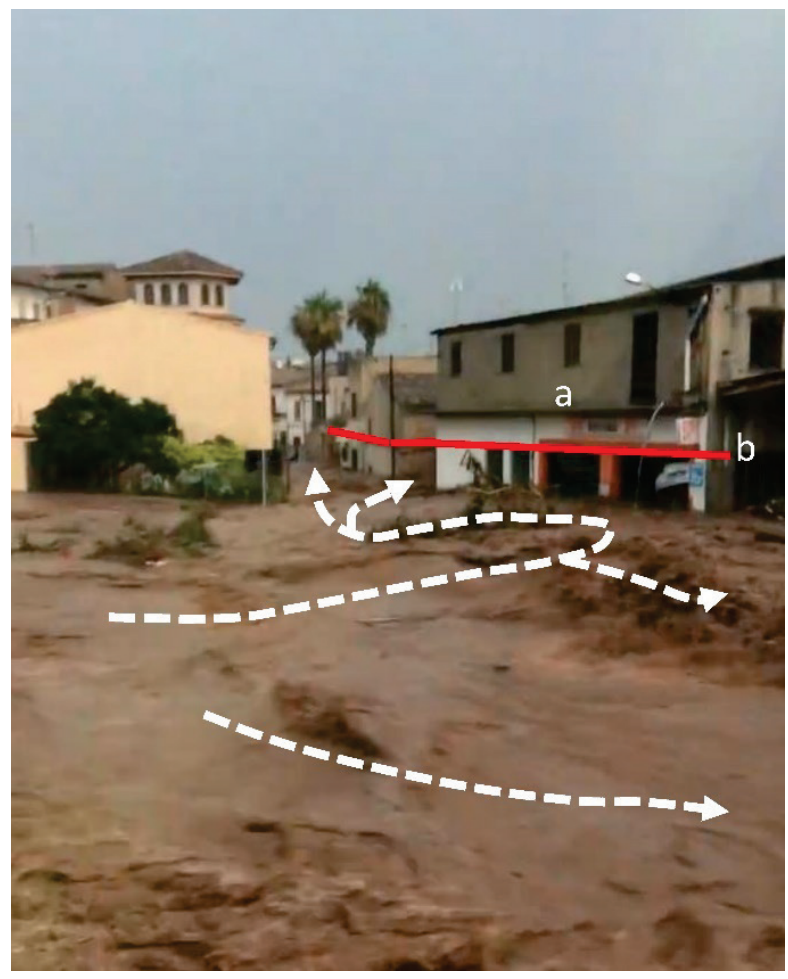

Figure 13. Image of the flood in the bridge Pont de Can Gostí minutes before the peak. The water flow is diverted by the warehouse adjacent to the watercourse (a). The peak of the flood was $2.8 \mathrm{~m}$ above the pavement (b).

The flood, hydrologically, is reduced to two avulsions in meandering sections of the torrent. In which the overflow water bypassed the meander and flooded a plain area, where the low part of the city and the sporting facilities are located. This scenario was worsened by the lack of capacity of the canal built in 1990, and by the presence of estate dividing walls in rural areas.

The lack of span of the bridges also obstructed the watercourse, since it made the water level rise and led the overflow water out of the canal. In other occasions, the bridges complicated the reintegration of the overflow water to the main course.

The warehouses and factories built in the 70s and 80s next to the water course also prevented the overflow from reintegrating into the main course. The effect of buildings is even more significant when located next to bridges, where the disturbance is maximal. The buildings in the surroundings of the bridge Pont de Can Gostí and next to the road to Son Servera had a detrimental role in the flooding of the village (Fig. 14).

The streets that are parallel to the course transformed into hydric channels. The urban development determined that some of the streets are crossed by other streets, buildings, or walls. These interruptions block the reintegration of water to the main channel and divert it towards other roads, which turns them into fluvial channels that do not respond to topography. These roads prolonged the flood to the east. 

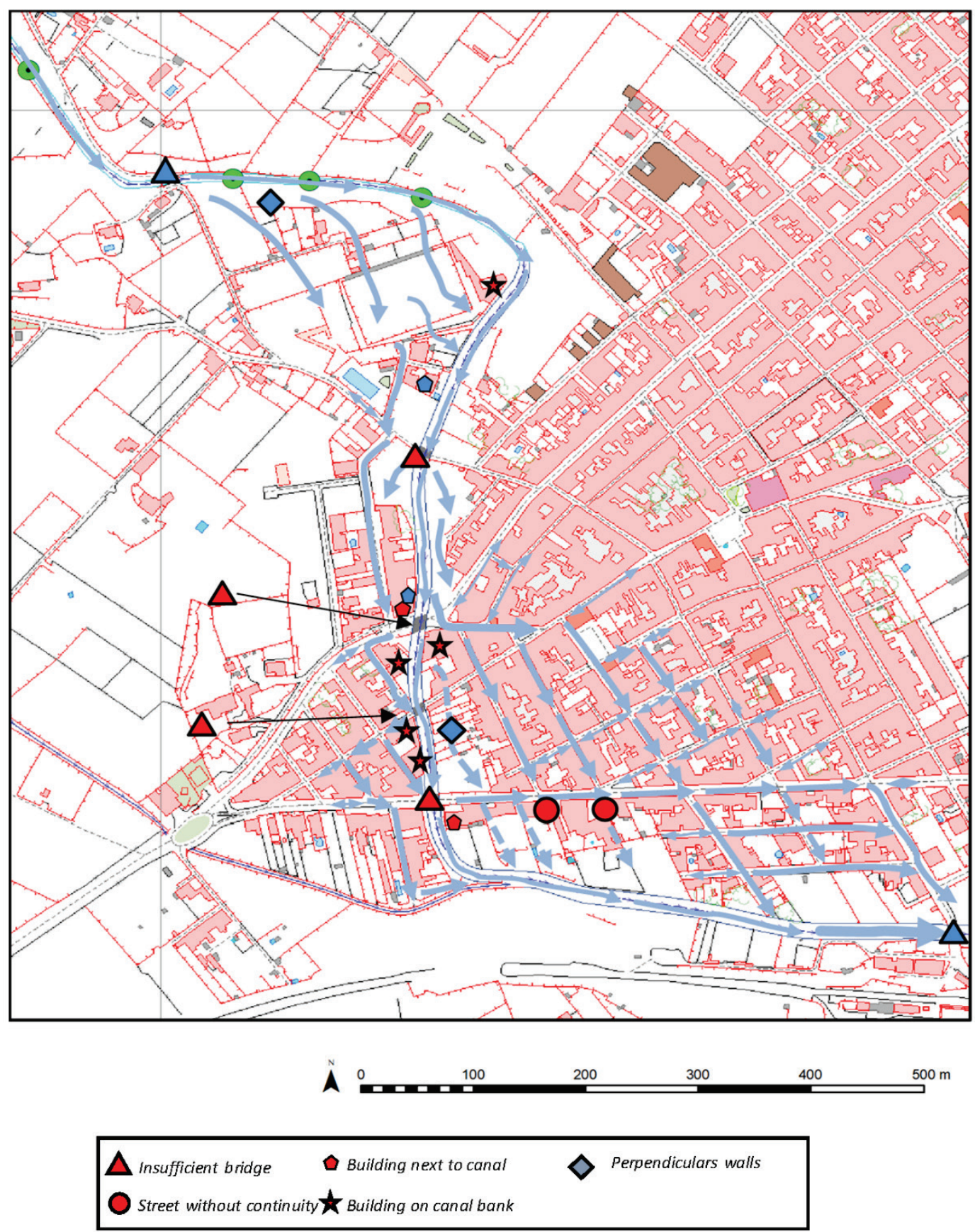

Figure 14. Topographic classification of the main obstacles and interferences to the watercourse in the urban area of Sant Llorenç des Cardassar.

\section{Discussion and conclusions}

The Sant Llorenç event is framed in a regional context of increased urban floods in Spain (Arranz, 2008), especially in coastal tourist areas (López et al., 2019). However, a set of factors make it a non-exemplary case: an urban area built for almost a century, a population center specifically not dedicated to tourism and an area with previous actions aimed at preventing floods and a basin that has not had radical changes in land use in recent decades. The very high number of fatalities, as well as the affectation of a large part of the population nucleus, highlight the danger of a large part of the Mediterranean area where events with a period of recurrence not well known can have extremely catastrophic effects. 
The flood of 2018 has been the most severe one suffered by the village of Sant Llorenç in the last 80 years, with flow peaks over $500 \mathrm{~m}^{3} / \mathrm{s}$. However, the rising was not an extreme event of flashflood since it did not instantly rise as it happened in 1998. The peak was relatively long and progressive in a span of time of about 15 minutes.

Sant Llorenç is located in an area where several watercourses join. The historical location of the village was not threatened by flooding, benefitting from a hill, and it was surrounded by the course of torrent de Ses Planes. The meanders of torrent de Ses Planes favour natural processes of avulsion in which the overflow bypasses the meanders and invades its lowest Banks.

The historical settlement of Sant Llorenç expanded moderately in the first half of the 20th century when the surroundings of the watercourse were urbanised following an orthogonal plan. The streets running north to south are parallel to the water course and have a similar slope. This expansion was previous to the demographic growth of Mallorca as a consequence of touristic development in the 60 s.

The main part of the buildings next to the watercourse had been built previous to the first flood that have affected the area since 1943. Several floods after this date put into manifest the danger of the low part of the village, but before that, there is no historical record of risk.

The administrative response to the floods has been the building of artificial cemented canals, which have been increasing in capacity after each flood. However, the channels have always been designed with an inferior capacity to the floods registered. The channels have been complemented with bridges with a narrow stem and extremely solidly built, which has worsened overflow and flooding.

The research and analysis of the 2018 flood shows that streets in the city centre constitute subsidiary watercourses in flooding events. These alternative watercourses usually flow following the natural overflowing lines and the topography of the area. However, the insufficient span of bridges, the buildings surrounding the channel, and the interruption of the streets that carry water provoke detrimental processes: they increase the level of overflow towards the streets and also hinder the reintegration of overflowing waters to the main watercourse.

The demolishing of unnecessary bridges, the widening of the span of the elemental bridges, the suppression of surrounding buildings, and the opening of the streets that act as watercourses, would diminish the area of affectation and the intensity of floods.

As a result of the previous actions, the village would have a dynamic hydric circulation of water which would allow water to flow, regardless of the possible insufficiency of capacity of the main channel. Overflowing waters could flow smoothly, and flood levels would be less critical and would not expand to such a wide area.

\section{Acknowledgements}

The authors would like to express gratitude towards everyone who has contributed with images, videos, witnesses and experiences, which are vital to reenact the flood event. The city council of Sant Llorenç has commissioned several technical reports about the flood, which have been the base for urban remodelling and improvement, the results of which are partially shown in the present paper.

\section{References}

Arranz, M. 2008. El riesgo de inundaciones y la vulnerabilidad en áreas urbanas. Análisis de casos en España. Estudios Geográficos, LXIX, 265, pp. 385-416. https://doi.org/10.3989/estgeogr.0417 
Bačová Mitková, V., Pekárová, P., Halmová, D. Miklánek, P. 2018. Reconstruction and post-event analysis of a flash flood in a small ungauged basin: a case study in Slovak territory. Nat Hazards 92, 741-760. https://doi.org/10.1007/s11069-018-3222-2

Costa, J.E. 1983. Paleohydraulic reconstruction of flash-flood peaks from boulder deposits in rhe Colorado Front Range. Geological Society of America Bulletin 94, 986-1004

Cortès, J. (coord.) 2019. Sa torrentada. Sant Llorenç des Cardassar. 9 octubre de 2019. Ajuntament de Sant Llorenç des Cardassar. Associació cultural Flor de Card. Palma. 478 pp.

Dalrymple, T., Benson, M.A. 1989. Measurement of Peak Discharge by the Slope-area Method. US Geological Survey.

Doswell, C.A. III, Brooks, H.E., Maddox R.A. 1996. Flash Flood Forecasting: An Ingredient-Based Methodology. Weather and Forecasting, 11, 560-581. https://doi.org/10.1175/15200434(1996)011<0560:FFFAIB>2.0.CO;2

Estrany, J., Grimalt, M. 2014. Catchment controls and human disturbances on the geomorphology of small Mediterranean estuaries systems. Estuarine Coastal and Shelf Science 150B, 230-241. https://doi.org/10.1016/j.ecss.2014.03.021

Grimalt, M. 1992. Geografia del risc a Mallorca. Les inundacions. Institut d’Estudis Baleàrics-CSIC. Palma. 374 pp.

Grimalt, M., Rodríguez, A. 1990. Caudales-punta de avenida y morfología de cuencas en Mallorca. In M. Gutiérrez, J.L. Peña, M.V. Lozano (Eds.), Actas I Reunión Nacional de Geomorfología. Sociedad Española de Geomorfología. Instituto de Estudios Turolenses, Teruel, 2, pp. 427-436.

Grimalt, M., Rosselló Geli, J. 2011. Anàlisi històrica de les inundacions a les Illes Balears segons la guia metodològica del Ministerio d'Agricultura, Alimentació i Medi Ambient. Conselleria d'Agricultura, Medi Ambient i Territori del Govern de les Illes Balears. 442 pp + Atlas.

Grimalt, M., Genovart, M.C. 2014. Caracterización espacio-temporal de las precipitaciones intensas en la vertiente litoral oriental de la isla de Mallorca (1930-2010). In: S. Fernández-Montes, F.S. Rodrigo (Eds). Cambio Climático y cambio global. Asociación Española de Climatología. pp. 447-457.

Grimalt, M., Rodríguez, A., Rodríguez, R. 1990. Morfometría de cuencas en la vertiente sudoriental de Mallorca. In O. Rullan, J.M. Seguí (Eds.). IV Coloquio de Geografía Cuantitativa. Los sistemas de información geográficos y la toma de decisiones territoriales. Universitat de les Illes Balears. AGE, Palma, pp. 355374.

Grimalt, M., Bauzà, J., Genovart, M.C. 2019a. Anàlisi de la torrentada del 9 d'octubre de 2018 al nucli urbà de Sant Llorenç: cabals, processos, interferències i propostes d'actuació. Estudio técnico. UIB. Grup de recerca de Climatologia, Hidrologia, Riscs Naturals i Territori. Ajuntament de Sant Llorenç des Cardassar. 49 pp.

Grimalt, M., Bauzà, J., Genovart, M.C. 2019b. La torrentada de 9 d’octubre de 2018 al terme de Sant Llorenç, una visió geogràfica. In: J. Cortès (coord.). Sa torrentada. Sant Llorenç des Cardassar. 9 octubre de 2019. Ajuntament de Sant Llorenç des Cardassar. Associació cultural Flor de Card. Palma. pp. 13-54.

Grimalt, M., Rodríguez, A., Rodríguez, R., Servera, J., Fornós, J. 1992. Procesos de colmatación en una albufera litoral (cala Magraner, Mallorca). In: F. López, C. Conesa, M. A. Romero (Edrs.). Estudios de geomorfologia en España: Actas de la II Reunión Nacional de Geomorfología. Murcia. pp. 529-536.

Grimalt-Gelabert, M., Rosselló-Geli, J., Bauzà-Llinàs. 2020. Flood related mortality in a touristic island: Mallorca (Balearic Islands) 1960-2018. Journal of Flood Risk Management. https://doi.org/10.1111/jfr3.12644

López, A., Mayer, P., Pacheco, J., Dorta, P. 2019. Rainfall and Flooding in Coastal Tourist Areas of the Canary Islands (Spain). Atmosphere 10 (12), 809. https://doi.org/10.3390/atmos10120809

Llasat, M.C., Llasat-Botija, M., Petrucci, O., Pasqua, A. A., Rosselló, J., Vinet, F., Boissier, L. 2013. Towards a database on societal impact of Mediterranean floods in the framework of the HYMEX project. Natural Hazards and Earth System Sciences 13, 1337-1350. https://doi.org/10.5194/nhess-13-1337-2013 
Macchione, F., Costabile, P., Costanzo, C., De Lorenzo, G. 2019. Extracting quantitative data from nonconventional information for the hydraulic reconstruction of past urban flood events. A case study. Journal of Hydrology 576, 443-465. https://doi.org/10.1016/j.jhydrol.2019.06.031

Portugués-Mollá, I., Bonache-Felici, X., Mateu-Bellés, J.F., Marco-Segura, J.B. 2016. A GIS-Based Model for the analysis of an urban flash flood and its hydro-geomorphic response. The Valencia event of 1957. Journal of Hydrology, 541A, 582-596. https://doi.org/10.1016/j.jhydrol.2016.05.048

Rico, M., Benito, G. 2002. Estimación de caudales de crecida en pequeñas cuencas de montaña: revisión metodológica y aplicación a la cuenca de Montardit (Pirineos Centrales, España). Cuaternario y Geomorfología 15, 125-138.

Riggs, H.C. 1976. A simplified slope-area method for estimating flood discharges in channels. Journal of Research of the US Geological Survey 4, 285-291.

Romero, A., Castejón, G. 2014. Inundaciones en la Región de Murcia en los inicios del siglo XXI. Biblio3W. Vol XIX, 41 pp.

Rosselló, V. M. 1964. Mallorca. El Sur y Sureste. Cámara Oficial de Comercio Industria y Navegación de Palma de Mallorca. Palma, 553 pp.

Segura-Beltran, F., Sanchis-Ibor, C., Morales-Hernández, M., González-Sanchis, M., Bussi, G., Ortiz, E. 2016 Using post-flood surveys and geomorphologic mapping to evaluate hydrological and hydraulic models: The flash flood of the Girona River (Spain) in 2007. Journal of Hydrology 541A, 310-329. https://doi.org/10.1016/j.jhydrol.2016.04.039 